\title{
Organs and carcass non-integrant components of Holstein calves, slaughtered at different weights, held in different finishing systems
}

\author{
Órgãos e componentes não integrantes da carcaça de bezerros \\ da raça holandesa abatidos com diferentes pesos, mantidos em \\ diferentes sistemas de terminação
}

\author{
Ana Maria Osorio Dias ${ }^{1}$; Luís Fernando Glasenapp de Menezes ${ }^{2 *}$; \\ Magali Floriano da Silveira'; Wagner Paris²; Priscila Vincenzi dos Santos 3 ; \\ Eduardo Felipe Colerauz de Oliveira Lazzarotto ${ }^{4}$
}

\begin{abstract}
The objective of this study was to evaluate the weight of the empty body and non-integrant components of Holstein calves carcass, kept in confinement system or pasture, slaughtered at different weights. We used 43 Holstein calves, entire, age and initial body weight of approximately 58 days and $57 \mathrm{~kg}$, distributed entirely at random in confinement or cultivated pasture. In feeding systems, it was prestipulated four slaughter weights (SW - 140, 180, 220 and $260 \mathrm{~kg}$ of live weight). In confinement, were provided corn silage and concentrate based on corn meal and soybean meal, in the ratio 40:60. The other animals in ryegrass pasture, followed by pearl millet, were fed based in supplementation of corn bran and soybean meal to $1 \%$ of live weight. The EBW showed linear growth with increasing slaughter weight (SW), as well as income from hot and cold carcass and there was no effect in relation EBW/ SW. The leather, the scraps, the head, the legs, as well as the sum of external components showed growth in its absolute weight as the weight increased at the slaughter of animals. In relative terms, the hot and cold carcass yields were inversely correlated with the relative weights, as well as external components (- 0.68 and -0.81$)$, the heart $(-0.35$ and $-0,38)$ lungs $(-0.53$ and -0.53$)$, the sum of the gastrointestinal tract $(-0.75$ and -0.77$)$, the sum of vital organs $(-0.71$ to -0.75$)$ respectively in feedlot and pasture. This is due to the different ages that the animals were slaughtered $(200 ; 237 ; 251$ and 263 days of age), due to prestipulate weights. The absolute weights of heart, kidney, lungs, liver, spleen, gall bladder, reproductive tract and gastrointestinal tract accompanied the increase in weight at animal's slaughter. However, when grouped, showed no difference related to the increase in weight at slaughter. The differences presented by the liver, trachea and spleen were sufficient to alter the absolute and relative weights of the set of internal components, where the animals finished on pasture had higher weight. The animals finished on pasture had higher absolute weights $(0.48$ against $1.18 \mathrm{~kg})$ and relatives $(0.31$ and $0.79 \%)$.
\end{abstract}

Key words: Confinement. Pasture. Empty body weight. Calves.

${ }^{1}$ Zootecnista, M.e em Zootecnia pela Universidade Tecnológica Federal do Paraná, UTFPR, Dois Vizinhos, PR, Brasil. E-mail: anamariaodias@hotmail.com

2 Profs. Drs., Zootecnistas, UTFPR, Dois Vizinhos, PR, Brasil. E-mail: luismenezes@utfpr.edu.br; magalisilveira@utfpr.edu.br; wagner@utfpr.edu.br

${ }_{3}$ Médica Veterinária, M.e em Zootecnia, UTFPR/DV, Dois Vizinhos, PR, Brasil. E-mail: priscila_vincvet@hotmail.com

${ }^{4}$ Zootecnista, Discente do Curso de Mestrado, Programa de Pós-Graduação em Zootecnia, UTFPR, Dois Vizinhos, PR, Brasil. E-mail: eduardo_felipe_lazzarotto@hotmail.com

* Author for correspondence 


\section{Resumo}

O objetivo do trabalho foi avaliar o peso do corpo vazio (PCVZ) e os componentes não-carcaça de 43 bezerros holandeses, não castrados, com idade de 58 dias e peso médio de $60 \mathrm{~kg}$, distribuídos ao acaso em confinamento ou pastagem cultivada. Em cada sistema, foram pré-estipulados quatro pesos de abate (PAB - 140, 180, 220 e $260 \mathrm{~kg}$ de peso vivo). No confinamento, foram fornecidos silagem de milho e concentrado à base de farelo de milho e farelo de soja, na relação 40:60. Os demais animais em pastagem cultivada de azevém e milheto, com suplementação a $1 \%$ do peso vivo. O PCVZ apresentou crescimento linear com o aumento do peso de abate, assim como os rendimentos de carcaça quente e fria e não houve efeito na relação PCVZ/PAB. O crescimento absoluto dos componentes externos foi proporcional ao aumento de peso. Em peso relativo ao PCVZ apenas a cabeça e as patas apresentaram diminuição em resposta ao aumento do peso vivo. O peso absoluto do coração, rins, pulmão, fígado, baço, vesícula biliar, traqueia, aparelho reprodutivo, TGI e o conteúdo do TGI elevaram-se linearmente. Em unidades relativas, o fígado, o esôfago, o trato gastrintestinal e o somatório dos componentes internos apresentaram decréscimo com o aumento do peso do animal. O peso absoluto do conteúdo do trato gastrintestinal, da traquéia, do baço e do somatório dos componentes internos, além do o peso relativo da cabeça, do fígado, do baço e do somatório dos componentes internos foram maiores nos animais terminados a pasto. Já os pesos absolutos das aparas e do couro, além do peso relativo do couro foram superiores nos animais terminados em confinamento.

Palavras-chave: Confinamento. Pastagem. Peso de corpo vazio. Vitelos.

\section{Introduction}

According to IBGE (2011), it is expected an average growth of $2.0 \%$ per year in the herd of dairy cows, from 23.6 million head in 2012 to 29.3 million head in 2023. This large number of animals generates a significant surplus of dairy calves, which is often discarded shortly after birth. In this context, strategies to study the termination of calves from dairy breeds become relevant, as it helps to increase beef production, and reduce a social and environmental problem.

In small dairy farms, production of these animals to pasture becomes costly, requires more time termination and, besides that, occupies the space designed to cows. The feedlot finishing becomes an alternative because provides, for shorter time, better quality carcasses, since Holstein animals are not well accepted by the refrigerators due to carcass yield, conformation and smaller deposition of subcutaneous fat than specialized breeds.

However, production systems differ as to the exploitation, feed digestibility and dietary fiber content, and consequently, the development of organs, such as heart, liver and gastrointestinal tract (NRC, 1996; KOSLOSKI, 2009). In addition, the study of the development of carcass non-integrant components becomes relevant as they may represent about 29.28 to $37.16 \%$ of slaughter weight and add value in sale of by-products to the refrigerator (PACHECO et al., 2005; RESTLE et al., 2005; MENEZES et al., 2007, 2009).

Another important aspect is under light of the carcass yield. Di Marco et al. (2007) reports that, in situations where the slaughter weight, body tissue composition and degree of carcasses finishing are similar, the weight and the empty body income are more likely to change due to nutritional factors as the fiber content and feed digestibility. These two factors can change the contents of digest and consequently the income of empty body weight / slaughter weight.

Thus, the aim of this study was assessing the weight of the empty body and non- integrant components of Holstein calves carcass, kept in confinement system or pasture, slaughtered at different weights. 


\section{Material and Methods}

The experiment period lasted from September 2011 to February 2012 in the Unit of Teaching and Research of Meat Cattle Breeding at Experimental Farm of Federal Technological University of Paraná (UTFPR) on campus Dois Vizinhos, situated at 25 42 '52' 'latitude $\mathrm{S}$ and longitude $53^{\circ} 03$ ' 94 ' $\mathrm{W}$, to 519 meters above sea level.

It were used 43 Holstein calves, uncastrated male, with initial age and average live weight of approximately 58 days and $57 \mathrm{~kg}$. The animals were randomly assigned to two finishing systems, in confinement or grazing on ryegrass, until complete the grazing cycle and after, distributed in grazing millet. Within each system, these were divided into four weights to the pre-stipulated slaughter (140, 180,220 and $260 \mathrm{~kg}$ live weight).

The experimental design was completely randomized in a factorial $2 \times 4$ (two finishing systems and four slaughter weights). Initially, it was planned to use six animals per treatment, but there have been some deaths at the beginning of the experiment because of weaning. Therefore, there were different repetitions in each treatment: finishing confinement system (5 animals slaughtered with $140 \mathrm{~kg} ; 6$ animals with $180 \mathrm{~kg}$; 6 animals with $220 \mathrm{~kg}$ and 6 animals with $260 \mathrm{~kg}$ ). And finishing system on pasture (6 animals slaughtered at $140 \mathrm{~kg} ; 5$ animals at $180 \mathrm{~kg}, 4$ animals with $220 \mathrm{~kg}$ and 5 animals at $260 \mathrm{~kg}$ ), where each animal is an experimental unit.

The period of adaptation to facilities and management system applied lasted 15 days. At weaning, around 57 days, the animals received injectable ADE vitamin, were wormed with Albendazol and weighed after solid fasting of 16 hours. The animals were not castrated and did not had the horns removed, but were vaccinated against clostridial diseases and foot-and-mouth disease, in accordance with the official vaccination schedule. The control of parasitic infections was performed by application of Ivermectin to $1 \%$ in all animals on the day of entry in the experiment. New applications were made every 28 days, on periodic weighing.

In confinement, were allocated 23 animals in individual stalls of $4 \mathrm{~m}^{2}$, receiving feed constituted of corn silage as commercial forage and concentrate pellet with $18 \%$ of crude protein, in a ratio of $40: 60$, respectively. The animals' diet was split into two daily meals, being provided $50 \%$ of the nutrition at 8:30 a.m. and the rest at 16:00 a.m. It was maintained a spare margin of $10 \%$ of the supplied nutrition, and the remains of the previous day weighed to estimate consumption.

The diet was formulated based on nutritional requirements established by the NRC (2001), for a daily weight gain expected of $1.0 \mathrm{~kg}$ (Table 1).

Table 1. Chemical composition of the feed provided in the experimental diets.

\begin{tabular}{cccccccc}
\hline \multirow{2}{*}{ Feed } & \multicolumn{7}{c}{ Variables } \\
\cline { 2 - 8 } & MS \% & PB \% & FDN\% & FDA\% & MM \% & NDT\% & DIVMS\% \\
\hline Concentrate & 84.00 & 19.00 & 18.02 & 9.27 & 6.90 & 69.88 & 79.24 \\
Silage & 28.73 & 8.38 & 45.14 & 30.16 & 1.58 & 60.51 & 57.13 \\
Ryegrass & 38.82 & 26.50 & 42.46 & 18.40 & 7.16 & 55.8 & 54.95 \\
Millet & 21.25 & 22.36 & 58.46 & 29.85 & 7.40 & 56.16 & 55.29 \\
\hline
\end{tabular}

The remaining 20 animals were finished on pasture, in variable sized area with cultivated pasture, according to the offer of pre-stipulated fodder. The grazing system used was continuous, with control of the forage supply by $10 \%$ of live weight through put and take technique, described 
by Mott and Lucas (1952), thus allowing the animals to select the most nutritious parts. The differentiation of the pasture was required by the cycle of it and speed of animals gain weight until they reach stipulated weights for slaughter.

In the first period, the animals were in ryegrass pasture (Lolium multiflorum), which had 418.52 $\mathrm{kg}^{\text {ha-1 }}$ of leaf blades in the period from September to November 2011 and at the two subsequent periods, in pearl millet (Pennisetum americanum), that provided a total of $2307.33 \mathrm{~kg}$ ha- 1 of leaf lamina from December 2011 to February 2012. Also received supplemental with commercial pelleted concentrate to $1 \%$ of live weight, as well as free access to water and mineral salt. The supplement was provided in the troughs 16 hours daily.

The weight measurements were taken every 28 days with food and water fasting for 16 hours and, as the animals of each treatment reached their weight stipulated for slaughter, they were driven to the slaughterhouse installed on Campus Dois Vizinhos. Immediately before slaughter, animals was weighted, being registered their slaughter weight.

The termination period is variable according to the slaughter weight (SW) according to the feeding system $(\mathrm{SW}=140 \mathrm{~kg}$ containment $(\mathrm{C})$ 110 days and the pasture (P) 168 days on average; $\mathrm{SW}=180 \mathrm{~kg}: \mathrm{C}=146, \mathrm{P}=219$ days; $\mathrm{SW}=220: \mathrm{C}$ $=166, \mathrm{P}=234 ; \mathrm{SW}=260: \mathrm{C}=167, \mathrm{P}=253$ days $)$. This variation within the termination systems is due to the different average daily weight gain of feeding systems, $0.703 \mathrm{~kg} \mathrm{day}^{-1}$ and $0.940 \mathrm{~kg}$ day1 for grazing and confinement, respectively.

During the slaughter, all parts of animal's body were separated and weighed individually, being: head, legs, ears, reproductive tract, horns (when present), tail broom and leather grouped as a set of external components, was also obtained lung weight, liver, kidneys, heart and spleen, trachea, gall bladder and gullet, grouped as a set of vital organs. Thus, the weight of rumen-reticulum, omasum, abomasum, large intestine, small intestine, grouped as full and empty digestive tract group.

Before sent to the cooling chamber, the two half-carcasses were identified and weighed, being obtained the hot carcass weight. The empty body weight was measured by the sum of the hot carcass weight and all components grouped into sets.

From the slaughter weights, empty body, hot carcass and cold carcass, were calculated incomes from hot and cold carcass in relation to slaughter weight and empty body.

The mathematical model used in this study was the one described below, being the initial weight of the animals used as a covariate:

$$
\text { Yijkl }=\mu+\text { PIK STi }+++ \text { PAJ }(S T * P A) i j+\text { Eijkl }
$$

where Yijkl $=$ dependent variables; $\mu=$ mean of all observations; PIK = effect of the k-th initial weight; STi $=$ effect of the ith termination system (pasture and confinement); PAJ = effect of the $\mathrm{j}$-th slaughter weight; $(\mathrm{ST} * \mathrm{PA}) \mathrm{ij}=$ interaction between termination system and slaughter weight; Eijkl = residual random error.

Data were subjected to analysis of variance, and when statistical difference was found, it was held the Polynomial Regression Analysis for the slaughter weights, and mean comparison, which have been classified by the test "F", with $\alpha=0.05$ of significance. The variables were also subjected to Pearson Correlation Analysis. Statistical analyzes were performed using the SAS ${ }$ software (SAS, 2002). 


\section{Results and Discussion}

There was no interaction between feeding systems and the slaughter weight for all the evaluated characteristics, thus the factors will be discussed separately.

It is observed that the empty body weight (EBW) and carcass yield in relation to $100 \mathrm{~kg}$ of EBW showed linear growth $(\mathrm{P}<0.05)$ as increased slaughter weight of animals. The increase of $1 \mathrm{~kg}$ in weight at slaughter provided an increase of 0.025 and $0.028 \%$ in income of hot and cold carcass, respectively (Table 2). These data were similar to those disclosed by Restle et al. (2005) and Kuss et al. (2007), which found an increase of empty body weight by higher slaughter weight in crossbred steers and cull cows crossbred Charolaise $\mathrm{x}$ Nellore, respectively. According to Brondani et al. (2004), carcass yield is influenced by factors such as race, age, type of diet, gender and toilet in the refrigerator slaughter line, and is highly affected by pre-slaughter fasting period. There was no correlation between absolute and relative weighs of gastrointestinal tract content with the yield of hot and cold carcass. This result shows that diet and pre-slaughter fasting had little influence on these characteristics.

Moreover, hot and cold carcass yields were inversely correlated $(\mathrm{p}<0.05)$ to relative weights of the head $(-0.67,-0.72)$, the legs $(-0.50$ to $0,61)$, external components $(-0.68$ and -0.81$)$, heart (- 0.35 and $-0,38)$, lungs (- 0.53 and -0.53$)$, gastrointestinal tract sum ( -0.75 and -0.77$)$, vital organs sum (- 0.71 to -0.75$)$. This is due to the different ages the animals were slaughtered (200; 237; 251 and 263 days of age), due to pre-stipulated weights (Table 2).
The increase in weight at slaughter determined linear increase $(\mathrm{P}<0.05)$ of GIC's weight. When this variable was expressed in relative units, as a function of empty body weight, this effect ceased to exist, demonstrating that there was no diet effect among slaughter weights.

There was no effect of slaughter weight on the relationship EBW / SW. Data from this study were lower than the 0.89 recommended by the NRC (2001) for Holstein calves with $150 \mathrm{~kg}$.

The leather, the scraps, the head, the legs, as well as the sum of external components showed growth in its absolute weight as increased the animals weigh at slaughter. Restle et al. (2005), when evaluating external components cattle housing, cite the importance of the absolute weight of the leather that is higher revenue per unit sold to refrigerators, being of more advantageous the slaughter of heavier animals, consequently, with more leather weight due to their greater representation within the external components.

Unlike of what occurred in the absolute weights, the relative weights of the head, feet and the sum of external components showed a decrease $(\mathrm{P}<0.05)$. This behavior was expected, since these components have early growth in early life and need to support animal's body growth. Missio et al. (2009) state that the highest percentage of feet is related to the early growth of bone tissue and to the reduction of age at slaughter with high concentrate content in the diet. In the work of Ribeiro et al. (2001), the feet relative weight decreased with the increasing age of the animal, as a result of tissue growth profile: first bone, then muscle and finally, fat. 
Table 2. Mean and standard error for empty body weight (EBW), hot carcass yield (RCQ) and income of the cold carcass (RCF) and external components (SEO), expressed in absolute weight (kg) and on $100 \mathrm{~kg}$ of empty body weight Holstein calves finished in different feeding systems.

\begin{tabular}{|c|c|c|c|c|c|c|}
\hline \multirow{2}{*}{ Variables } & \multicolumn{4}{|c|}{ Slaughter Weight (kg de LW) } & \multicolumn{2}{|c|}{$\mathrm{P}^{1}$ Value } \\
\hline & 144.6 & 179.77 & 227.56 & 260.51 & $\mathrm{~L}$ & Q \\
\hline Empty body weight, $\mathrm{kg}^{2}$ & $112.62 \pm 3.51$ & $140.16 \pm 2.97$ & $175.23 \pm 2.79$ & $206.60 \pm 3.03$ & $<.0001$ & 0.5587 \\
\hline $\mathrm{RCQ}, \%^{3}$ & $62.05 \pm 0.57$ & $62.61 \pm 0.48$ & $63.60 \pm 0.45$ & $65.28 \pm 0.49$ & $<.0001$ & 0.3499 \\
\hline $\mathrm{RCF}, \%^{4}$ & $59.65 \pm 0.57$ & $59.90 \pm 0.48$ & $62.00 \pm 0.45$ & $62.73 \pm 0.49$ & $<.0001$ & 0.7913 \\
\hline Relation EBW/SW & $0.80 \pm 0.01$ & $0.77 \pm 0.01$ & $0.79 \pm 0.01$ & $0.79 \pm 0.01$ & 0.7759 & 0.5780 \\
\hline GIC content, $\mathrm{kg}^{5}$ & $19.35 \pm 1.50$ & $25.26 \pm 1.50$ & $29.46 \pm 1.66$ & $31.22 \pm 1.58$ & $<.0001$ & 0.4985 \\
\hline GIC content, $\%$ & 16. $78 \pm 1.50$ & $18.44 \pm 1.27$ & $16.73 \pm 1.19$ & $15.60 \pm 1.30$ & 0.3227 & 0.5217 \\
\hline \multicolumn{7}{|c|}{ External Components } \\
\hline Leather, $\mathrm{Kg}^{6}$ & $10.55 \pm 0.39$ & $14.17 \pm 0.39$ & $17.86 \pm 0.43$ & $21.68 \pm 0.41$ & $<.0001$ & 0.8738 \\
\hline Leather $\%$ of EBW & $9.47 \pm 0.27$ & $10.25 \pm 0.22$ & $10.14 \pm 0.21$ & $10.66 \pm 0.23$ & 0.0614 & 0.4208 \\
\hline Scraps, $\mathrm{Kg}^{7}$ & $1.11 \pm 0.27$ & $1.79 \pm 0.27$ & $2.61 \pm 0.30$ & $2.94 \pm 0.29$ & 0.0033 & 0.0992 \\
\hline Scraps $\%$ of EBW & $1.25 \pm 0.17$ & $1.37 \pm 0.15$ & $1.50 \pm 0.14$ & $1.24 \pm 0.15$ & 0.9343 & 0.848 \\
\hline Head, $\mathrm{Kg}^{8}$ & $6.13 \pm 0.23$ & $7.13 \pm 0.23$ & $8.34 \pm 0.25$ & $9.56 \pm 0.24$ & $<.0001$ & 0.3256 \\
\hline Head \% do EBW ${ }^{9}$ & $5.73 \pm 0.21$ & $5.08 \pm 0.17$ & $4.78 \pm 0.16$ & $4.60 \pm 0.18$ & 0.0017 & 0.1704 \\
\hline Legs, $\mathrm{Kg}^{10}$ & $4.30 \pm 0.16$ & $4.91 \pm 0.16$ & $5.78 \pm 0.18$ & $6.70 \pm 0.17$ & $<.0001$ & 0.1559 \\
\hline Legs $\%$ of EBW ${ }^{11}$ & $3.97 \pm 0.12$ & $3.49 \pm 0.10$ & $3.31 \pm 0.09$ & $3.29 \pm 0.10$ & $<.0001$ & 0.0337 \\
\hline $\mathrm{SEO}, \mathrm{kg}^{12}$ & $34.31 \pm 0.80$ & $38.65 \pm 0.80$ & $43.26 \pm 0.89$ & $49.10 \pm 0.84$ & $<.0001$ & 0.2159 \\
\hline $\mathrm{SEO}, \% 0^{13}$ & $31.72 \pm 0.71$ & $27.80 \pm 0.60$ & $24.75 \pm 0.56$ & $23.99 \pm 0.61$ & $<.0001$ & 0.0151 \\
\hline
\end{tabular}

${ }^{1} \mathrm{~L}$ and $\mathrm{Q}$ : effects of linear and quadratic growth related to increased slaughter weight;

${ }^{2} \mathrm{EBW}=-21.36954+0.37610 * \mathrm{PI}+0.79434 * \mathrm{PAB}\left(\mathrm{r}^{2}=0.95\right)$;

${ }^{3} \mathrm{RCQ}=60.21032-0.03174 * \mathrm{PI}+0.02508 * \mathrm{PAB}\left(\mathrm{r}^{2}=0.42\right)$

${ }^{4} \mathrm{RCF}=5.52344-0.00087707 * \mathrm{PI}+0.02831 * \mathrm{PAB}\left(\mathrm{r}^{2}=0.46\right)$;

${ }^{5} \mathrm{GIC}=7.99455-0.04975 * \mathrm{PI}+0.10566 * \mathrm{PAB}\left(\mathrm{r}^{2}=0.42\right)$;

${ }^{6}$ Leather $=-4.73505+0.05482 * \mathrm{PI}+0.08961 * \mathrm{PAB}\left(\mathrm{r}^{2}=0.89\right)$;

${ }^{7}$ Scraps $=-0.20584+0.00558 * \mathrm{PI}+0.01013 * \mathrm{PAB}\left(\mathrm{r}^{2}=0.25\right)$;

${ }^{8} \mathrm{Head}=1.54095+0.01312+0.02758 * \mathrm{PI} * \mathrm{PAB}\left(\mathrm{r}^{2}=0.67\right)$;

${ }^{9}$ Head $=6.93568-0.00602 * \mathrm{PI}-0.00799 * \mathrm{PAB}\left(\mathrm{r}^{2}=0.29\right)$;

${ }^{10}$ Legs $=1.29426+1.29426+0.01874 * \mathrm{PI} * \mathrm{PAB}\left(\mathrm{r}^{2}=0.72\right)$;

${ }^{11}$ Legs $=4.96189-0.00400 * \mathrm{PI}-0.00612 * \mathrm{PAB}\left(\mathrm{r}^{2}=0.43\right)$;

${ }^{12} \mathrm{SEO}=15.48461+0.06354 * \mathrm{PI}+0.11297 * \mathrm{PAB}\left(\mathrm{r}^{2}=0.79\right)$;

${ }^{13} \mathrm{SEO}=41.71719-0.03080 * \mathrm{PI}-0.06527 * \mathrm{PAB}\left(\mathrm{r}^{2}=0.71\right)$.

Similarly of external components, the absolute weights of the heart, kidney, lungs, liver, spleen, gall bladder, reproductive tract and gastrointestinal tract accompanied $(\mathrm{P}<0.05)$ the increase in weight at slaughter of animals. However, when grouped, showed no difference with the increase in weight at slaughter (Table 3).
Costa et al. (2002), in a study of young calves slaughtered prematurely (14 months old), commented that internal organs and viscera present early development and the phenomenon occurs with greater intensity in early stages of animal's life, explaining linear growth. Signoretti et al. (1999), claim that heart and lung growths, in absolute weight, is hardly negatively influenced, indicating that these organs maintain their integrity (SIGNORETTI et al., 1999). 
Table 3. Mean and standard error of Internal Components (IOC) in absolute weight $(\mathrm{kg})$ and relative (\% of empty body weight - EBW), Holstein calves finished with different weights.

\begin{tabular}{|c|c|c|c|c|c|c|}
\hline \multirow{2}{*}{ Internal Components } & \multicolumn{4}{|c|}{ Slaughter Weight (kg de SW) } & \multicolumn{2}{|c|}{$\mathrm{P}^{1}$ Values } \\
\hline & 144.6 & 179.77 & 227.56 & 260,51 & $\mathrm{~L}$ & $\mathrm{Q}$ \\
\hline Heart, $\mathrm{kg}^{2}$ & $0.73 \pm 0.05$ & $0.87 \pm 0.05$ & $1.00 \pm 0.05$ & $1.16 \pm 0.05$ & $<.0001$ & 0.9945 \\
\hline Heart, \% & $0.66 \pm 0.05$ & $0.65 \pm 0.04$ & $0.57 \pm 0.04$ & $0.55 \pm 0.04$ & 0.0592 & 0.9304 \\
\hline Kidneys, $\mathrm{kg}^{3}$ & $0.75 \pm 0.08$ & $1.02 \pm 0.08$ & $1.34 \pm 0.09$ & $1.46 \pm 0.08$ & $<.0001$ & 0.0967 \\
\hline Kidneys, \% & $0.74 \pm 0.06$ & $0.78 \pm 0.05$ & $0.78 \pm 0.05$ & $0.66 \pm 0.05$ & 0.3355 & 0.0850 \\
\hline Lung, $\mathrm{kg}^{4}$ & $2.04 \pm 0.12$ & $2.14 \pm 0.12$ & $2.38 \pm 0.13$ & $2.92 \pm 13$ & $<.0001$ & 0.0854 \\
\hline Lung, \% & $1.67 \pm 0.09$ & $1.44 \pm 0.07$ & $1.35 \pm 0.07$ & $1.43 \pm 0.07$ & 0.221 & 0.0327 \\
\hline Liver, $\mathrm{kg}^{5}$ & $2.78 \pm 0.13$ & $3.19 \pm 0.13$ & $3.86 \pm 0.15$ & $4.21 \pm 0.14$ & $<.0001$ & 0.6295 \\
\hline Liver, $\%^{6}$ & $2.66 \pm 0.10$ & $2.33 \pm 0.08$ & $2.20 \pm 0.08$ & $2.08 \pm 0.09$ & 0.0026 & 0.4332 \\
\hline Spleen, $\mathrm{kg}$ & $0.72 \pm 0.09$ & $0.77 \pm 0.09$ & $0.82 \pm 0.10$ & $1.01 \pm 0.09$ & 0.0463 & 0.3832 \\
\hline Spleen, \% & $0.67 \pm 0.06$ & $0.57 \pm 0.05$ & $0.48 \pm 0.04$ & $0.47 \pm 0.05$ & 0.7616 & 0.4407 \\
\hline Gall bladder, kg & $0.13 \pm 0.03$ & $0.20 \pm 0.02$ & $0.13 \pm 0.03$ & $0.25 \pm 0.03$ & 0.0296 & 0.2885 \\
\hline Gall bladder, \% & $0.11 \pm 0.02$ & $0.14 \pm 0.01$ & $0.07 \pm 0.01$ & $0.13 \pm 0.01$ & 0.8240 & 0.3875 \\
\hline Trachea, $\mathrm{kg}^{7}$ & $0.55 \pm 0.06$ & $0.50 \pm 0.06$ & $0.51 \pm 0.07$ & $0.50 \pm 0.06$ & $<.0001$ & 0.2876 \\
\hline Trachea, $\%$ & $0.27 \pm 0.02$ & $0.32 \pm 0.02$ & $0.27 \pm 0.02$ & $0.25 \pm 0.02$ & 0.7944 & 0.2048 \\
\hline Gullet, kg & $0.23 \pm 0.02$ & $0.22 \pm 0.02$ & $0.26 \pm 0.02$ & $0.30 \pm 0.02$ & 0.0520 & 0.5943 \\
\hline Gullet, $\%^{8}$ & $0.20 \pm 0.01$ & $0.17 \pm 0.01$ & $0.15 \pm 0.01$ & $0.14 \pm 0.01$ & 0.0024 & 0.2538 \\
\hline Rep. System, kg $^{9}$ & $0.49 \pm 0.06$ & $0.67 \pm 0.05$ & $0.84 \pm 0.06$ & $0.94 \pm 0.06$ & $<.0001$ & 0.7798 \\
\hline Rep. System \% & $0.41 \pm 0.04$ & $0.44 \pm 0.04$ & $0.47 \pm 0.03$ & $0.49 \pm 0.04$ & 0.6521 & 0.9311 \\
\hline $\mathrm{GIC}^{*}, \mathrm{~kg}^{10}$ & $13.59 \pm 0.54$ & $17.53 \pm 0.54$ & $20.49 \pm 0.60$ & $23.98 \pm 0.57$ & $<.0001$ & 0.3385 \\
\hline GIC, $\%{ }^{11}$ & $12.48 \pm 0.38$ & $12.99 \pm 0.32$ & $11.85 \pm 0.30$ & $11.20 \pm 0.33$ & 0.0032 & 0.2754 \\
\hline IOC, kg & $22.81 \pm 0.69$ & $22.38 \pm 0.69$ & $22.74 \pm 0.76$ & $23.78 \pm 0.72$ & 0.2053 & 0.4131 \\
\hline IOC, $\%{ }^{12}$ & $20.74 \pm 0.64$ & $16.36 \pm 0.54$ & $13.08 \pm 0.51$ & $11.50 \pm 0.56$ & $<.0001$ & 0.0445 \\
\hline
\end{tabular}

* GIC = gastrointestinal tract ${ }^{1} \mathrm{~L}$ and Q: effects of linear and quadratic growth related to increased slaughter weight;

${ }^{2}$ Heart $=0.16944+0.00226 * \mathrm{PI}+0.00328 * \mathrm{PAB}\left(\mathrm{r}^{2}=0.40\right)$;

${ }^{3}$ Kidneys $=0.27953-0.00048434 * \mathrm{PI}+0.00458 * \mathrm{PAB}\left(\mathrm{r}^{2}=0.40\right)$;

${ }^{4}$ Lung $=0.13839+0.00665 * \mathrm{PI}+0.00902 * \mathrm{PAB}\left(\mathrm{r}^{2}=0.54\right)$

${ }^{5}$ Liver $=0.51680+0.00854 * \mathrm{PI}+0.01288 * \mathrm{PAB}\left(\mathrm{r}^{2}=0.66\right) ;$

${ }^{6}$ Liver $=2.94725+0.00068465 * \mathrm{PI}-0.00349 * \mathrm{PAB}\left(\mathrm{r}^{2}=0.26\right) ;$

${ }^{7}$ Trachea $=-0.05347+0.00172 * \mathrm{PI}+0.00198 * \mathrm{PAB}\left(\mathrm{r}^{2}=0.41\right) ;$

${ }^{8}$ Gullet $=0.27622-0.00004865 * \mathrm{PI}-0.00053394 * \mathrm{PAB}\left(\mathrm{r}^{2}=0.26\right)$;

${ }^{9}$ Reproductive System $=0.24470-0.00552 * \mathrm{PI}+0.00396 * \mathrm{PAB}\left(\mathrm{r}^{2}=0.38\right)$;

${ }^{10} \mathrm{GIC}=-0.27660+0.07604 * \mathrm{PI}+0.07558 * \mathrm{PAB}\left(\mathrm{r}^{2}=0.83\right) ;$

${ }^{11} \mathrm{GIC}=13.59887+0.01858 * \mathrm{PI}-0.01237 * \mathrm{PAB}\left(\mathrm{r}^{2}=0.25\right)$;

${ }^{12} \mathrm{IOC}=30.30405-0.02548 * \mathrm{PI}-0.06876 * \mathrm{PAB}\left(\mathrm{r}^{2}=0.73\right)$.

When expressed in relative weights, liver, gullet, gastrointestinal tract and sums of internal components showed a decrease $(\mathrm{P}<0.05)$ in their participation with increasing slaughter weight. According Berg and Butterfield (1976), the vital organs present further development at an earlier stage of the animal life and, as the animal's age advances, the rate of growth of muscle tissue, especially adipose, is higher. Thus, internal organs represent a smaller proportion of empty body weight. According to findings of authors (ALMEIDA et al., 2001; JORGE; FONTES, 2001), the vital organs as well as the animal's body tissues, have different maximum growth rates at 
different times. This speed of development can also be affected by adult body size and hormones (JORGE; FONTES, 2001), by age and other environmental causes (COLEMAN et al., 1993). Signoretti et al. (1999), disclose that the higher requirement of liquid energy for maintenance of Holstein cattle, at the beginning of growth phase, partly, may be due to the larger size of internal organs, especially the liver. This organ is the most susceptible to variations, as it accounts for metabolic rates and energy requirements, altered according to consumption. Among all organs, is the one that is most demanding (RIBEIRO et al., 2001; KOZLOSKI, 2009; OWENS et al., 1993; FERRELL; JENKINS, 1998).

The increase in the absolute weight of the gastrointestinal tract presented similar results to the ones reported by Carvalho et al. (2003), who used Holstein calves from birth to 110 days of age in their studies. These authors claim that such behavior, in part, is due to high initial growth of rumen-reticulum, which quintupled its tissue weight from birth to 50 days of age, converting calf in functional ruminant at 50 days of life. After these 50 days, these authors observed that the gastrointestinal tract contents increased from 50 to 110 days $\left(176.6 \mathrm{~g} \mathrm{day}^{-1}\right)$, concluding that such values indicate there is a greater growth of stomach tissue until 50 days. From this date on, the increase of total weight of the organ is more remarkable as gastrointestinal content (GC). However, in this study, despite the weight of gastrointestinal tract contents have increased, absolute weights of gastrointestinal tract decreased.

As weights were pre-set for the slaughter, there was no difference to empty body weight (EBW) between feeding systems (Table 4). The same result for yield of hot and cold carcass, in relation to empty body weight and relationship EBW / SW. Menezes et al. (2011), observed relations EBW / SW $0.83 ; 0.85$ and 0.82 for super young cattle
(18 months old) in confinement, temperate and tropical clime pasture, respectively, values higher than those found in this work. That is because of the relationship of EBW / SW of 0.79 for both systems, confinement and pasture. Hot and cold carcass yields were similar between the feeding systems. Feeds showed fiber content in neutral detergent fiber (NDF) very close (28.8 and 27.8\% for feedlot and pasture, respectively), which leads to deduce that feeding did not influence yields. Vaz et al. (2005) found no difference in carcass yield, comparing diets with different levels of NDF or different levels of concentrate, in agreement to this study, which concluded that the performance did not vary significantly.

Gastrointestinal tract contents were altered only when expressed as absolute weight $(\mathrm{P}<0.05)$. Carvalho et al. (2003) stated that the NDF content of the diet is a major contributor to rumen and of gastrointestinal tract filling, fact linked to higher NDF present in pastures, especially in millet phase, conditioning greater weight of GIC in animals treated in pasture. However, this difference in gastrointestinal tract content was not enough to influence the carcass yield, noting that there was no correlation between absolute and relative weights of gastrointestinal tract content with proceeds of hot and cold carcass.

Among external components, scraps and leather were components that represent significance ( $\mathrm{P}$ $<0.05)$ in absolute weights and just leather and head in relative weights. As already explained, leather is one of the most important components economically speaking, once it adds value from harvesting to processing into marketable products (RESTLE et al., 2005; PACHECO et al., 2005). Moreover, all external components showed no difference between finishing systems. It is expected that the lower the weight of these components, the greater will be the carcass yield (RESTLE et al., 2005), explaining, in part, the lack of carcass yield difference. 
Table 4. Means and standard error for empty body weight (EBW), hot carcass yield (WHR) and income of the cold carcass $(\mathrm{RCF})$, gastrointestinal tract contents and external components, expressed in absolute weight $(\mathrm{kg})$ and relative weight $100 \mathrm{~kg}$ of empty body weight (EBW) of Holstein calves finished in different feeding systems.

\begin{tabular}{lcccc}
\hline \multirow{2}{*}{ Variables } & \multicolumn{2}{c}{ Feeding System } & \multirow{2}{*}{$\mathrm{P}<\mathrm{F}$} & \multirow{2}{*}{ CV \% } \\
\cline { 2 - 3 } & Confinement & Pasture & & \\
\hline Empty body weight, kg & $158.92 \pm 2.05$ & $158.39 \pm 2.42$ & 0.8756 & 5,13 \\
RCQ, \% of EBW & $63.82 \pm 0.33$ & $62.95 \pm 0.39$ & 0.1252 & 2,15 \\
RCF, \% of EBW & $61.34 \pm 0.33$ & $60.80 \pm 0.39$ & 0.3374 & 2,22 \\
Relation EBW/SW & $0.79 \pm 0.01$ & $0.79 \pm 0.01$ & 0.8706 & 5,12 \\
GIC Content kg & $23.09 \pm 1.07$ & $28.75 \pm 1.16$ & 0.0056 & 19,16 \\
GIC Content, \% & $15.80 \pm 0.88$ & $17.97 \pm 1.04$ & 0.1443 & 21,36 \\
\hline & Carcass External Components & & \\
\hline Scraps, kg & $2.56 \pm 0.19$ & $1.66 \pm 0.21$ & 0.0049 & 42,56 \\
Scraps, \% & $1.49 \pm 0.10$ & $1.19 \pm 0.12$ & 0.0978 & 31,65 \\
Head, kg & $7.56 \pm 0.16$ & $8.01 \pm 0.18$ & 0.0840 & 10,01 \\
Head, \% & $4.75 \pm 0.12$ & $5.35 \pm 0.14$ & 0.0071 & 10,11 \\
Leather, kg & $16.80 \pm 0.27$ & $15.33 \pm 0.30$ & 0.0014 & 8,02 \\
Leather, \% & $10.64 \pm 0.15$ & $9.62 \pm 0.18$ & 0.0006 & 6,29 \\
Legs, kg & $5.46 \pm 0.11$ & $5.39 \pm 0.12$ & 0.7013 & 10,11 \\
Legs, \% & $3.49 \pm 0.07$ & $3.54 \pm 0.08$ & 0.7246 & 8,31 \\
External components, kg & $41.55 \pm 0.57$ & $41.09 \pm 0.62$ & 0.6015 & 6,44 \\
\multicolumn{1}{c}{ External components, \% } & $26.73 \pm 0.41$ & $27.40 \pm 0.49$ & 0.3329 & 6,36 \\
\hline
\end{tabular}

In this study, finishing system did not alter the absolute and relative weights of most organs (Table 5). Vital organs such as heart, kidneys and lung maintain their integrity, as animal development, keeping pace with metabolic rates and presenting priority in nutrients intake and utilization (RIBEIRO et al., 2001).

Liver and spleen were influenced $(\mathrm{P}=0.0514)$ by feeding system, where animals finished on pasture had higher absolute and relative values (Table 5). That comes in agreement with Menezes et al. (2011), who explains the greater weight of the liver of animals fed on grass by higher crude protein content of forage, compared to diets based in concentrate. The amount in those diets is from $9 \%$ to $10 \%$ for animals in confinement. However, it was expected that animals finished in feedlot submitted a greater weight of these organs, due to increased supply of nutrients, mainly via concentrate. et al. (2001) reported that calves livers responds very quickly to feed exchange and feed consumption, noting that further development is directly linked to metabolisable energy intake, as well as free feed that will allow more weight to the organ. Despite daily protein intake (0.82 against 0.93 ) did not present difference $(\mathrm{P}>0.05)$, animals finished on pasture had higher total consumption of BP, once they took longer time to reach the slaughter weight. Silva et al. (2002) observed an increase in weight of Nellore calves liver when increased crude protein content in diets from 15 to $18 \%$, and no difference when raised the concentrate content from 20 to $80 \%$. Therefore, it may be concluded that diets with good nutritional value of roughage are able to supply maximum development of organs. 
Table 5. Vital organs of the Holstein calves in absolute weight $(\mathrm{kg})$ and relative weight (100 $\mathrm{kg} \mathrm{EBW})$ finished in different feeding systems.

\begin{tabular}{lcccc}
\hline \multirow{2}{*}{ Vital organs } & \multicolumn{2}{c}{ Feeding System } & \multirow{2}{*}{$\mathrm{P}<\mathrm{F}$} & \multirow{2}{*}{ CV \% } \\
\cline { 2 - 3 } & Confinement & Pasture & & \\
\hline Heart, kg & $0.90 \pm 0.03$ & $0.98 \pm 0.04$ & 0.1436 & 18,90 \\
Heart, \% & $0.58 \pm 0.03$ & $0.64 \pm 0.03$ & 0.2686 & 21,22 \\
Kidneys, kg & $1.20 \pm 0.06$ & $1.09 \pm 0.06$ & 0.2503 & 24,72 \\
Kidneys, \% & $0.74 \pm 0.03$ & $0.74 \pm 0.04$ & 0.9888 & 21,15 \\
Lung, kg & $2.32 \pm 0.08$ & $2.41 \pm 0.09$ & 0.5099 & 17,19 \\
Lung, \% & $1.48 \pm 0.05$ & $1.47 \pm 0.06$ & 0.9455 & 12,73 \\
Liver, kg & $3.36 \pm 0.09$ & $3.66 \pm 0.10$ & 0.0514 & 12,39 \\
Liver, \% & $2.20 \pm 0.06$ & $2.44 \pm 0.07$ & 0.0272 & 11,02 \\
Trachea, kg & $0.41 \pm 0.04$ & $0.62 \pm 0.05$ & 0.0060 & 41,99 \\
Trachea, \% & $0.27 \pm 0.01$ & $0.28 \pm 0.02$ & 0.7488 & 25,63 \\
Gall bladder, kg & $0.17 \pm 0.02$ & $0.19 \pm 0.02$ & 0.5415 & 50,43 \\
Gall bladder, \% & $0.11 \pm 0.01$ & $0.12 \pm 0.01$ & 0.8284 & 46,65 \\
Gullet, kg & $0.24 \pm 0.01$ & $0.27 \pm 0.01$ & 0.2904 & 25,83 \\
Gullet, \% & $0.15 \pm 0.01$ & $0.17 \pm 0.01$ & 0.3254 & 25,11 \\
Spleen, kg & $0.48 \pm 0.06$ & $1.18 \pm 0.7$ & $<.0001$ & 37,13 \\
Spleen, \% & $0.31 \pm 0.03$ & $0.79 \pm 0.04$ & $<.0001$ & 28,88 \\
Reproductive System, kg & $0.69 \pm 0.04$ & $0.78 \pm 0.04$ & 0.1702 & 25,69 \\
Reproductive System, \% & $0.45 \pm 0.02$ & $0.45 \pm 0.03$ & 0.9585 & 24,91 \\
GIC, kg & $19.10 \pm 0.39$ & $18.70 \pm 0.42$ & 0.5034 & 9,59 \\
GIC \% & $11.92 \pm 0.22$ & $12.34 \pm 0.26$ & 0.2715 & 7,50 \\
Internal Components, kg & $21.45 \pm 0.49$ & $24.39 \pm 0.53$ & 0.0004 & 9,99 \\
Internal Components, \% & $14.29 \pm 0.38$ & $16.55 \pm 0.44$ & 0.0013 & 10,44 \\
\hline
\end{tabular}

Animals finished on pasture had higher absolute weights (0.48 against $1.18 \mathrm{~kg})$ and relative weights $(0.31$ and $0.79 \%)$. The spleen plays production and purification functions of blood cells, with possibility of interfering and be involved in fat metabolism (MENEZES et al., 2011). Ferrell et al. (1976) stated that spleen increases when nutrient intake is higher, especially energy and protein, actively participating in these nutrients metabolism. Crude protein intake of calves showed no difference between treatments, with averages of 0.82 and $0.93 \mathrm{~kg}$ and 0.64 and $0.72 \%$, respectively, for animals finished in feedlot or pasture. However, there was difference for dry matter intake (5.65 against $4.33 \mathrm{~kg}$ and 4.36 against $3.32 \%$ of live weight), NDT (3.70 against $2.58 \mathrm{~kg}$ and 2.88 and $2.01 \%$ of live weight) and
FDA (0.98 against $0.66 \mathrm{~kg}$ and 0.76 against $0.51 \%$ of live weight).

The differences presented by liver, trachea and spleen were sufficient to alter absolute and relative weights of the set of internal components $(\mathrm{P}<0.05)$, where animals finished in pasture presented higher weight.

\section{Conclusions}

Finishing system, pasture or confinement did not influence in carcass yield of Holstein calves.

Considering different slaughter weights, carcass yield of calves increased proportionally as there was a decrease in relative weight of the sets of external organs and internal organs. 


\section{References}

ALMEIDA, M. I. V.; FONTES, C. A. A.; ALMEIDA, F. Q.; VALADARES FILHO, S. C.; GUIMARÃES, R. F. Avaliação do crescimento de tecidos e órgãos de novilhos mestiços holandês-Gir durante o ganho compensatório. 2. Tecidos e órgãos. Revista Brasileira de Zootecnia, Viçosa, MG, v. 30, n. 2, p. 526-534, 2001.

BERG, R. T.; BUTTERFIELD, R. M. New concepts of cattle growth. New York: Sydney University, 1976. 240 p.

BRONDANI, I. L.; SAMPAIO, A. A. M.; RESTLE, J.; BERNARDES, R. A. L. C.; PACHECO, P. S.; FREITAS, A. K. D.; KUSS, F.; PEIXOTO, L. A. D. O. Aspectos quantitativos de carcaças de bovinos de diferentes raças, alimentados com diferentes níveis de energia. Revista Brasileira de Zootecnia, Santa Maria, RS, v. 33, n. 4, p. 978-988, 2004.

CARVALHO, P. A.; SANCHEZ, L. M. B.; VIÉGAS, J.; VELHO, J. P.; JAURIS, G. C.; RODRIGUES, M. B. Componentes do peso vivo e órgãos viscerais de bezerros machos de origem leiteira ao nascimento, 50 e 110 dias de vida. Revista Brasileira de Zootecnia, Viçosa, MG, v. 32, n. 6, p. 1469-1475, 2003.

COLEMAN, S. W.; EVANS, B. C.; GUENTHER, J. J. Body and carcass composition of Angus and Charolais steers as affected by age and nutrition. Journal of Animal Science, Champaign, v. 71, n. 1, p. 86- 95, 1993.

COSTA, E. C.; RESTLE, J.; VAZ, F. N.; ALVES FILHO, D. C.; BERNARDES, R. A. L. C.; KUSS, F. Características da carcaça de novilhos Red Angus superprecoces abatidos com diferentes pesos. Revista Brasileira de Zootecnia, Viçosa, MG, v. 31, n. 1, p. 119-128, 2002.

DI MARCO, O. N.; BARCELLOS, J. O. J.; COSTA, E. C. Crescimento de bovinos de corte. Porto Alegre: Universidade Federal do Rio Grande do Sul, 2007. 276 p.

FERRELL, C. L.; GARRETT, W. N.; HINMAN, N. Estimation of body composition in pregnant and nonpregnant heifers. Journal of Animal Science, Champaign, v. 42, n. 5, p. 1158-1166, 1976.

FERRELL, C. L.; JENKIS, T. G. Body composition and energy utilization by steers of diverse genotypes fed a high-concentrate diet during the finishing period: Angus, Boran, Brahman, Hereford and Tuli Sires. Journal of Animal Science, Champaign, v. 76, n. 2, p. 647-657, 1998.

INSTITUTO BRASILEIRO DE GEOGRAFIA E ESTATÍSTICA - IBGE. Sistema de recuperação de informações - SIDRA. Brasília: IBGE, 2011. Disponível em: <http:/www.sidra.ibge.gov.br>. Acesso em: 25 fev. 2016.
JORGE, A. M.; FONTES, C. A. A. Desenvolvimento relativo das partes do corpo de zebuínos de quatro raças. Ciência Rural, Santa Maria, v. 31, n. 5, p. 857-861, 2001.

KOZLOSKI, G. V. Bioquimica de ruminantes. 2. ed. rev. ampl. Santa Maria: Imprensa Universitária, UFSM, 2009. $216 \mathrm{p}$.

KUSS, F.; RESTLE, J.; BRONDANI, I. L.; PASCOAL, L. L.; MENEZES, L. F. G.; LEITE, D. T.; SANTOS, M. F. Órgãos vitais e trato gastrintestinal de vacas de descarte mestiças Charolês $\times$ Nelore abatidas com pesos distintos. Revista Brasileira de Zootecnia, Viçosa, MG, v. 36, n. 2, p. 421-429, 2007.

MENEZES, L. F. G.; BRONDANI, I. L.; RESTLE, J.; ALVES FILHO, D. C.; CALLEGARO, A. M.; WEISE, M. Características dos componentes não integrantes da carcaça de novilhos superjovens da raça Devon, terminados em diferentes sistemas de alimentação, Arquivo Brasileiro de Medicina Veterinária e Zootecnia, Belo Horizonte, v. 63, n. 2, p. 372-381, 2011.

MENEZES, L. F. G.; RESTLE, J.; BRONDANI, I. L.; ALVES FILHO, D. C.; PASCOAL, L. L.; SILVA, J. H. S. Distribuição de gorduras internas e de descarte e componentes externos do corpo de novilhos de geração avançadas do cruzamento rotativo entre as raças Charolês e Nelore. Revista Brasileira de Zootecnia, Viçosa, MG, v. 38, n. 2, p. 338-345, 2009.

MENEZES, L. F. G.; RESTLE, J.; BRONDANI, I. L.; KUSS, F.; ALVES FILHO, D. C.; SILVEIRA, M. F.; LEITE, D. T. Órgãos internos e trato gastrintestinal de novilhos de gerações avançadas do cruzamento rotativo entre as raças Charolês e Nelore terminados em confinamento. Revista Brasileira de Zootecnia, Viçosa, MG, v. 36, n. 1, p. 120-129, 2007.

MISSIO, R.; BRONDANI, I. L.; RESTLE, J.; SILVA, J. H. S.; SILVEIRA, M. F.; SILVA, V. S. Partes nãointegrantes da carcaça de tourinhos alimentados com diferentes níveis de concentrado na dieta. Revista Brasileira de Zootecnia, Viçosa, MG, v. 38, n. 5, p. 906915, 2009.

MOTT, G. O.; LUCAS, H. L. The design, conduct and interpretation of grazing trials on cultivated and inproved pastures. In: INTERNATIONAL GRASSLAND CONGRESS, 6., 1952, Pennsylvania. Procedings... Pennsylvania: State College press, 1952. p. 1380-1385.

NATIONAL RESEARCH COUNCIL - NRC. Nutrient requirements of dairy cattle. $7^{\text {th }}$ ed. Washington, D.: National Academy Press, 2001. 381 p.

Nutrient requirements of domestic animals. $7^{\text {th }}$ rev. ed. Washington, D. C.: National Academy Press, 1996. 242 p. 
OWENS, F. N.; DUBESKI, P.; HANSON, C. F. Factors that alter the growth and development of ruminants. Journal of Animal Science, Champaign, v. 71, n. 11, p. 3138-3150, 1993.

PACHECO, P. S.; RESTLE, J.; SILVA, J. H. S.; ARBOITTE, M. Z.; ALVES FILHO, D. C.; FREITAS, A. K.; ROSA, J. R. P.; PÁDUA, J. T. Características das partes do corpo não-integrantes da carcaça de novilhos jovens e superjovens de diferentes grupos genéticos. Revista Brasileira de Zootecnia, Viçosa, MG, v. 34, n. 5, p. 1666-1677, 2005.

RESTlE, J.; MENEZES, L. F. G.; ARBOITTE, M. Z.; PASCOAL, L. L.; PACHECO, P. S.; PÁDUA, J. T. Características das partes não-integrantes da carcaça de novilhos $5 / 8$ Nelore $3 / 8$ Charolês abatidos em três estádios de desenvolvimento. Revista Brasileira de Zootecnia, Viçosa, MG, v. 34, n. 4, p. 1339-1348, 2005.

RIBEIRO, T. R.; PEREIRA, J. C.; LEÃO, M. I.; OLIVEIRA, M. V. M.; QUEIROZ, A. C.; CECON, P. R.; MELO, R. C. A. Tamanho de órgãos e vísceras de bezerros Holandeses, para produção de vitelos, recebendo dietas com diferentes níveis de concentrado. Revista Brasileira de Zootecnia, Viçosa, MG, v. 30, n. 6, p. 2163-2168, 2001.
STATISTICAL ANALYSIS SYSTEM INSTITUTE SAS Institute. SAS/STAT. User's guide: statistics, versão 9. 0. 5. ed. Cary: SAS USA Institute, 2002.

SIGNORETTI, R. D.; SILVA, J. F. C.; VALADARES FILHO, S. C.; PEREIRA, J. C.; CECON, P. R.; ARAÚJO, G. G. L.; QUEIROZ, A. C. Composição corporal e exigências líquidas de energia e proteína de bezerros da Raça Holandesa alimentados com dietas contendo diferentes níveis de volumoso. Revista Brasileira de Zootecnia, Viçosa, MG, v. 28, n. 1, p. 195-204, 1999.

SILVA, F. F.; VALADARES FILHO, S. C.; ÍTAVO, L. C. V.; VELOSO, C. M.; VALADARES, R. F. D.; CECON, P. R.; PAULINO, P. V. R.; MORAES, E. B. K. Composição corporal e requisitos energéticos e proteicos de bovinos Nelore, não-castrados, alimentados com rações contendo diferentes níveis de concentrado e proteína. Revista Brasileira de Zootecnia, Viçosa, MG, v. 31, n. 1, p. 503513, 2002. Suplemento.

VAZ, F. N.; RESTLE, J.; SILVA, N. L. Q.; ALVES FILHO, D. C.; PASCOAL, L. L.; BRONDANI, I. L.; KUSS, F. Nível de concentrado, variedade da silagem de sorgo e grupo genético sobre a qualidade da carcaça e da carne de novilhos confinados. Revista Brasileira de Zootecnia, Viçosa, MG, v. 34, n. 1, p. 239-248, 2005. 